\title{
Effect of Profile Characteristics on Stubble Burning Behaviour of farmers in Punjab
}

\author{
Arpit Huria*, Neelam Bhardwaj and Neelam Basera \\ Agricultural Extension and Communication, GBPUAT, Pantnagar, U.S. Nagar, \\ Uttarakhand, India \\ *Corresponding author
}

\section{A B S T R A C T}

The problem of stubble burning has grown to be of utmost concern in past few years especially in Northern India. The most prevalent rice-wheat cropping system

\section{Keywords}

Stubble burning, Farmers, Punjab, Profile

characteristics

Article Info

Accepted:

17 January 2021

Available Online:

10 February 2021 in states like Punjab, Haryana, Uttar Pradesh etc. features harvesting of paddy crop with mechanical combine harvesters which leaves a huge amount of stubble which is commonly burnt by the farmers for speedy sowing of next crop. The stubble burning in northern states is held responsible for several environmental and health issues which immediately needs to be addressed. Despite herculean efforts including judicial and legislative measures, the problem of stubble burning seems far from ending. Maximum number of stubble burning incidents was recorded from the state of Punjab. So, a study was carried out to find out which profile characteristics influence the stubble burning behaviour of farmers in Punjab. A total of 15 variables were taken for the study. Coefficient of correlation was found out for variables with ungrouped data while chi-square test was applied for grouped data variables to determine the relationships. It was found that only economic motivation of the farmers was in a positive and significant relationship with the stubble burning behaviour of the farmers.

\section{Introduction}

Rice-wheat cropping system is most prominent in India. The Indo-Gangetic plains in Northern India accounts for around twelve million hectares of rice and wheat crop rotation and harvesting of these crops with combine harvesters is very popular with the farmers. The mechanized harvesting leaves a large quantity of stubble that takes a lot of time to decompose in the soil and is usually burnt for speedy plantation of the next crop. This method of removing dry stubble by burning it to prepare the field for subsequent planting is called as stubble burning. India generates around $600 \mathrm{Mt}$ of stubble which includes about 90-140 Mt of surplus stubble and is likely to be burned in the field (Jain et 
al., 2014). Multipurpose use of stubble includes animal feeding, soil mulching, biomanure, thatching for rural homes and fuel for domestic and industrial use. Despite knowing of alternative methods of stubble management, farmers burn a significant portion of the crop stubble on-farm so that the succeeding crop can be sown on a cleared field. Mechanized farming coupled with lack of availability of farm labour and high cost associated with the process further exacerbates the problem of stubble burning. In fact, according to a study conducted by International Food Policy Research Institute, air pollution due to stubble burning in northern India causes an estimated economic loss of around USD 30 billion annually, and is a leading cause of acute respiratory infections, especially among children; apart from various ill-effects to environment (Chakrabarti et al., 2019).

Punjab is one of the chief contributors to the country's total food grain production. In Punjab, the farmers largely follow the ricewheat cropping system. Rice is usually grown in the Kharif season (sown in July-August and harvested in October-November) and wheat in the Rabi season (sown in NovemberDecember and harvested in April-May). The major constraint in the rice-wheat cropping system is the availability of short span of time between the harvesting of rice and sowing of wheat. Rice and wheat are double cropped in Punjab with rice stubble being burned off over millions of acres prior to the planting of wheat.Any delay in sowing adversely affects the production and yield of the subsequent wheat crop. The preparation of field involves removal or utilization of rice stubble left in the field.

Over a period of time, various modern inputs have been introduced in Punjab to harvest the rice crop within such a short span of time. One such input is the combined mechanized harvester which has now become the most popular implement used for harvesting in the rice-wheat cropping system. The use of the combined harvester has increased at a tremendous rate in Punjab over a period of time. Almost 80 per cent of the rice crop is harvested by it. However, the use of the combined harvester has also enhanced the problem of crop stubble management. The use of combined harvesters leaves behind a large amount of rice stubble in the fields which is difficult to collect. It has been widely observed that farmers find burning the stubble as the easiest and the most economical way of getting rid of it. The stubble burning also facilitates the farmers to speed up the sowing of subsequent wheat crop in the short span of time. Thus, burning has emerged as the standard method of rice stubble management in the combine harvested rice-wheat cropping system that is practised on a broad scale in Punjab.

Every year, almost 15 million tonnes of paddy stubble is generated in Punjab. Of this, according to various estimates, on an average, almost half of the rice stubble is set on fire in open fields (Kumar et al, 2015). The stubble burning is monitored through Satellite Remote Sensing by NICRA, IARI-CESRA, New Delhi. The data highlights that the total number of stubble burning incidents recorded during $1^{\text {st }}$ October 2018- 30 ${ }^{\text {th }}$ November 2018 were 75,563 . Out of which, majority of the burning incidents were recorded in Punjab $(59,695)$. Whereas the number of stubble burning incidents in Haryana and Uttar Pradesh were found to be 9232 and 6696 respectively (Chhabra et al, 2019). The above-mentioned period is the peak time for paddy harvesting in these states.

According to Kumar et al., (2019), among all the stubble burning incidents in Punjab, the Malwa region accounted for almost 95 per cent of the total crop stubble burning 
incidents. Therefore, the Malwa region was selected purposively as the locale for the study.

Further, this study attempted to determine the effect of profile variables on the stubble burning behaviour of the farmers. The stubble burning behaviour of the farmers was defined as the act of burning the left-over paddy stubble on farm, after harvesting by the farmers. It was measured using two dimensions, namely frequency and proportion. The frequency referred to number of times stubble burnt by the farmers in last five years. The proportion referred to the approximate amount of stubble (in percentage) managed through burning by the farmers. Both the dimensions were rated on 5point continuum and a cumulative score was considered for the overall stubble burning behaviour of the farmers. The profile variables taken for the study after reviewing thorough literature and consultation with experts were: age, gender, education, size of land holding, annual income, livestock possession, type of farming, information seeking behaviour, innovativeness, risk orientation, scientific orientation, ecological consciousness, economic motivation, awareness about stubble management measures and cropping intensity. These variables were measured using appropriate scales and formulae.

\section{Materials and Methods}

In order to find out the relationship between the profile characteristics and the stubble burning behaviour of the farmers, the correlation test and chi-square test wereapplied using Statistical Package for Social Sciences. To explore the relationships, Pearson's product moment correlation coefficient (r) has been used to test the hypotheses concerning the relationships of independent variables with ungrouped data.
Five per cent and one per cent level of significance were used as the basis of acceptance or rejection of a hypothesis. The values of the correlation coefficient range from -1 to 1 . The sign of the correlation coefficient indicates the direction of the relationship (positive or negative) between the two variables under study. The absolute value of the correlation coefficient indicates the strength, with larger absolute values indicating stronger relationships.

On the other hand, the significance level (or p-value) is the probability of obtaining results as extreme as the one observed. The significance value (p) indicates the basis for acceptance and rejection of the hypothesis under study. This, further, states whether the relationship is significant or has occurred by chance and hence, is non-significant. If the calculated significance level is small than the designated level of significance $(\alpha=0.01$ or 0.05 ), then the null hypothesis was rejected and it was concluded that there was a statistically significant relationship between the concerned variables where the two variables are linearly related. Alternately, if the calculated significance value (p) was relatively large/greater than the designated level of significance $(\alpha=0.01$ or 0.05$)$, the null hypothesis was accepted. Thus, it was concluded that there was not enough evidence to show the statistically significant relationship between the concerned variables under study and thus, the two variables are not linearly related.

Regarding the variables with grouped data such as gender, education and type of farming, the chi-square test was applied to test the respective hypotheses stating the independence between the variables and stubble burning behaviour of the farmers. The chi-square value was calculated $\left(\square^{2}\right.$ cal) and compared with the chi-square tabulated value ( $\square^{2}$ tab) at respective degree of freedom. If the 
chi-square tabulated value exceeded the chisquare calculated value, then the null hypothesis stating the independence between the variables was accepted, otherwise it was rejected.

\section{Results and Discussion}

The results of the correlation co-efficient between the characteristics of the farmers and stubble burning behaviour with their significance value is shown in Table 1 and the relationships are described below.

\section{Age}

The relationship between age of the farmers and their stubble burning behaviour was examined by testing the following null hypothesis: "There is no significant relationship between the age of the farmers and their stubble burning behaviour". As shown in the Table 1, the calculated value of coefficient of correlation between two variables at $5 \%$ level of significance was found to be $0.084(\mathrm{r}=0.084)$ and the calculated significance value 'p' was 0.094 respectively. The ' $r$ ' value indicates very weak strength of co-relation between the two variables, whereas, 'p' value was more than $\alpha$ value (0.05). This indicates a statistically nonsignificant positive relationship between the age of the farmers and their stubble burning behaviour. Hence, null hypothesis $\mathrm{H}_{01}$ was accepted.

\section{Size of land holding}

The relationship between size of land holding of the farmers and their stubble burning behaviour was examined by testing the following null hypothesis: "There is no significant relationship between the size of land holding of the farmers and their stubble burning behaviour". As shown in the Table 1, the calculated value of coefficient of correlation between two variables at 5\% level of significance was found to be $0.006(\mathrm{r}=$ $0.006)$ and the calculated significance value ' $p$ ' was 0.926 respectively. The ' $r$ ' value indicates very weak strength of co-relation between the two variables, whereas, 'p' value was more than $\alpha$ value (0.05). This indicates a statistically non-significant positive relationship between the size of land holding of the farmers and their stubble burning behaviour. Hence, null hypothesis $\mathrm{H}_{02}$ was accepted.

\section{Annual income}

The relationship between annual income of the farmers and their stubble burning behaviour was examined by testing the following null hypothesis: "There is no significant relationship between the annual income of the farmers and their stubble burning behaviour". As shown in the Table 1, the calculated value of coefficient of correlation between two variables at 5\% level of significance was found to be $-0.008(\mathrm{r}=-$ 0.008 ) and the calculated significance value ' $p$ ' was 0.895 respectively. The ' $r$ ' value indicates very weak strength of co-relation between the two variables, whereas, the negative sign indicates that with the increase in annual income there was found to be decrease in the stubble burning behaviour. The ' $p$ ' value was found to be more than $\alpha$ value $(0.05)$. This indicates a statistically nonsignificant negative relationship between the annual income of the farmers and their stubble burning behaviour. Hence, null hypothesis $\mathrm{H}_{03}$ was accepted.

The negative correlation indicates that there was a decrease in stubble burning behaviour with the increase in the annual income of farmers. This explains the fact that farmers who were well off, tried other stubble management measures despite being costly. 


\section{Livestock possession}

The relationship between livestock possession of the farmers and their stubble burning behaviour was examined by testing the following null hypothesis: "There is no significant relationship between the livestock possession of the farmers and their stubble burning behaviour". As shown in the Table 1, the calculated value of coefficient of correlation between two variables at $5 \%$ level of significance was found to be $0.046(\mathrm{r}=$ 0.046 ) and the calculated significance value 'p' was 0.474 respectively. The ' $r$ ' value indicates very weak strength of co-relation between the two variables, whereas, the ' $p$ ' value was found to be more than $\alpha$ value (0.05). This indicates a statistically nonsignificant positive relationship between the livestock possession of the farmers and their stubble burning behaviour. Hence, null hypothesis $\mathrm{H}_{04}$ was accepted.

\section{Information seeking behaviour}

The relationship between information seeking behaviour of the farmers and their stubble burning behaviour was examined by testing the following null hypothesis: "There is no significant relationship between the information seeking behaviour of the farmers and their stubble burning behaviour". As shown in the Table 1, the calculated value of coefficient of correlation between two variables at $5 \%$ level of significance was found to be $-0.099(\mathrm{r}=-0.099)$ and the calculated significance value 'p' was 0.122 respectively. The ' $r$ ' value indicates very weak strength of co-relation between the two variables, whereas, the negative sign indicates that with the increase in information seeking behaviour there was a decrease in the stubble burning behaviour. The ' $p$ ' value was found to be more than $\alpha$ value $(0.05)$. This indicates a statistically non-significant negative relationship between the information seeking behaviour of the farmers and their stubble burning behaviour. Hence, null hypothesis $\mathrm{H}_{05}$ was accepted.

The negative correlation indicates that there was a decrease in stubble burning behaviour with the increase in the information seeking behaviour of farmers. This explains the fact that farmers who possessed high degree of information seeking behaviour, gathered information on various agricultural related areas from different sources like input retail shops, company agents, relatives, progressive farmers, television, mobile phones, etc. and tried other stubble management measures than burning.

\section{Innovativeness}

The relationship between innovativeness of the farmers and their stubble burning behaviour was examined by testing the following null hypothesis: "There is no significant relationship between the innovativeness of the farmers and their stubble burning behaviour". As shown in the Table 1, the calculated value of coefficient of correlation between two variables at 5\% level of significance was found to be 0.015 ( $\mathrm{r}=$ 0.015 ) and the calculated significance value ' $p$ ' was 0.817 respectively. The ' $r$ ' value indicates very weak strength of co-relation between the two variables, whereas, the ' $p$ ' value was found to be more than $\alpha$ value (0.05). This indicates a statistically nonsignificant positive relationship between the innovativeness of the farmers and their stubble burning behaviour. Hence, null hypothesis $\mathrm{H}_{06}$ was accepted.

\section{Risk orientation}

The relationship between risk orientation of the farmers and their stubble burning behaviour was examined by testing the following null hypothesis: "There is no 
significant relationship between the risk orientation of the farmers and their stubble burning behaviour". As shown in the Table 1, the calculated value of coefficient of correlation between two variables at $5 \%$ level of significance was found to be 0.011 ( $\mathrm{r}=$ 0.015 ) and the calculated significance value ' $p$ ' was 0.864 respectively. The ' $r$ ' value indicates very weak strength of co-relation between the two variables, whereas, the ' $p$ ' value was found to be more than $\alpha$ value (0.05). This indicates a statistically nonsignificant positive relationship between the risk orientation of the farmers and their stubble burning behaviour. Hence, null hypothesis $\mathrm{H}_{07}$ was accepted.

\section{Scientific orientation}

The relationship between scientific orientation of the farmers and their stubble burning behaviour was examined by testing the following null hypothesis: "There is no significant relationship between the scientific orientation of the farmers and their stubble burning behaviour". As shown in the Table 1, the calculated value of coefficient of correlation between two variables at 5\% level of significance was found to be 0.045 ( $\mathrm{r}=$ 0.045 ) and the calculated significance value 'p' was 0.848 respectively. The ' $r$ ' value indicates very weak strength of co-relation between the two variables, whereas, the ' $p$ ' value was found to be more than $\alpha$ value (0.05). This indicates a statistically nonsignificant positive relationship between the scientific orientation of the farmers and their stubble burning behaviour. Hence, null hypothesis $\mathrm{H}_{08}$ was accepted.

\section{Ecological consciousness}

The relationship between ecological consciousness of the farmers and their stubble burning behaviour was examined by testing the following null hypothesis: "There is no significant relationship between the ecological consciousness of the farmers and their stubble burning behaviour". As shown in the Table 1 , the calculated value of coefficient of correlation between two variables at $5 \%$ level of significance was found to be 0.001 ( $\mathrm{r}$ $=0.001$ ) and the calculated significance value ' $p$ ' was 0.966 respectively. The ' $r$ ' value indicates very weak strength of co-relation between the two variables, whereas, the ' $p$ ' value was found to be more than $\alpha$ value (0.05). This indicates a statistically nonsignificant positive relationship between the ecological consciousness of the farmers and their stubble burning behaviour. Hence, null hypothesis $\mathrm{H}_{09}$ was accepted.

\section{Economic motivation}

Economic motivation was one of the factors believed to have an effect on the stubble burning behaviour of the farmers. The relationship between economic motivation of the farmers and their stubble burning behaviour was examined by testing the following null hypothesis: "There is no significant relationship between the economic motivation of the farmers and their stubble burning behaviour". As shown in the Table 1, the calculated value of coefficient of correlation between two variables at $1 \%$ level of significance was found to be 0.495 ( $\mathrm{r}=$ 0.495 ) and the calculated significance value ' $p$ ' was 0.023 respectively. The ' $r$ ' value indicates the moderate strength of co-relation between the two variables, whereas, ' $p$ ' value was less than $\alpha$ value (0.05). This indicates a statistically significant positive relationship between economic motivation of the farmers and their stubble burning behaviour. Hence, null hypothesis $\mathrm{H}_{010}$ was rejected.

As most of the farmers were having high economic motivation, this might be one of the key factors in choosing a stubble management measure. Since, stubble burning is the most 
economical measure available, most of the farmers preferred it instead of going for other alternatives. This also helps in deducing the reason behind farmers reverting back to burning after trying the alternative measures as they were costly and didn't yield fruitful results.

\section{Awareness regarding alternative stubble management measures}

The relationship between awareness of the farmers regarding alternative stubble management measures and their stubble burning behaviour was examined by testing the following null hypothesis: "There is no significant relationship between the awareness of the farmers regarding alternative stubble management measures and their stubble burning behaviour". As shown in the Table 1, the calculated value of coefficient of correlation between two variables at 5\% level of significance was found to be 0.012 ( $\mathrm{r}=$ 0.012 ) and the calculated significance value ' $p$ ' was 0.260 respectively. The ' $r$ ' value indicates very weak strength of co-relation between the two variables, whereas, the ' $p$ ' value was found to be more than $\alpha$ value (0.05). This indicates a statistically nonsignificant positive relationship between the awareness of the farmers regarding alternative stubble management measures and their stubble burning behaviour. Hence, null hypothesis $\mathrm{H}_{011}$ was accepted.

\section{Cropping intensity}

The relationship between the cropping intensity and their stubble burning behaviour was examined by testing the following null hypothesis: "There is no significant relationship between the cropping intensity and stubble burning behaviour of the farmers". As shown in the Table 1, the calculated value of coefficient of correlation between two variables at 5\% level of significance was found to be $0.041(\mathrm{r}=0.041)$ and the calculated significance value ' $p$ ' was 0.518 respectively. The ' $r$ ' value indicates very weak strength of co-relation between the two variables, whereas, the ' $p$ ' value was found to be more than $\alpha$ value (0.05). This indicates a statistically non-significant positive relationship between the cropping intensity and stubble burning behaviour of the farmers. Hence, null hypothesis $\mathrm{H}_{012}$ was accepted.

\section{Gender}

Since, the data regarding gender was grouped data, therefore chi-square was used to test the hypothesis between gender of the farmers and their stubble burning behaviour. The null hypothesis stated for this variable was: "The gender of the farmers and their stubble burning behaviour are independent". The results of chi-square test as shown in Table 2 reveals that the calculated chi-square value was $3.903\left(\square^{2}\right.$ cal= 3.903) while the tabulated chi-square value was $5.991\left(\square^{2}\right.$ tab $\left.=5.991\right)$ at 2 degrees of freedom. This indicates that chisquare calculated value was less than chisquare tabulated ( $\square^{2}$ cal $<\square^{2}$ tab), which means that both the variables, gender and stubble burning behaviour were independent. Hence, null hypothesis $\mathrm{H}_{013}$ was accepted.

he data regarding education was also grouped data, hence, chi-square was used to test the hypothesis between education of the farmers and their stubble burning behaviour. The null hypothesis stated for this variable was: "The education of the farmers and their stubble burning behaviour are independent". The results of chi-square test as shown in Table 3 reveals that the calculated chi-square value was $8.720\left(\square^{2}\right.$ cal $\left.=8.720\right)$ while the tabulated chi-square value was $21.026\left(\square^{2}\right.$ tab $\left.=21.026\right)$ at 12 degrees of freedom. This indicates that chi-square calculated value was less than chisquare tabulated ( $\square^{2}$ cal $<\square^{2}$ tab), which means 
that both the variables, education and stubble burning behaviour were independent. Hence, null hypothesis $\mathrm{H}_{014}$ was accepted.

\section{Type of farming}

As the data regarding type of farming was also grouped data, therefore chi-square was used to test the hypothesis between type of farming and the stubble burning behaviour of the farmers. The null hypothesis stated for this variable was: "The type of farming and stubble burning behaviour of the farmers are independent".

Table. 1 The relationship between profile characteristics (ungrouped data) and stubble burning behaviour of farmers

\begin{tabular}{|l|l|c|c|}
\hline S. No. & Variables & $\begin{array}{c}\text { Calculated correlation } \\
\text { coefficient values "r" }\end{array}$ & $\begin{array}{c}\text { Calculated significance } \\
\text { value "p" }\end{array}$ \\
\hline 1. & Age & $0.084^{\mathrm{NS}}$ & 0.094 \\
\hline 2. & Size of land holding & $0.006^{\mathrm{NS}}$ & 0.926 \\
\hline 3. & Annual Income & $-0.008^{\mathrm{NS}}$ & 0.895 \\
\hline 4. & Livestock possession & $0.046^{\mathrm{NS}}$ & 0.474 \\
\hline 5. & Information seeking behaviour & $-0.099^{\mathrm{NS}}$ & 0.122 \\
\hline 6. & Innovativeness & $0.015^{\mathrm{NS}}$ & 0.817 \\
\hline 7. & Risk Orientation & $0.011^{\mathrm{NS}}$ & 0.864 \\
\hline 8. & Scientific Orientation & $0.045^{\mathrm{NS}}$ & 0.848 \\
\hline 9. & Ecological consciousness & $0.001^{\mathrm{NS}}$ & 0.986 \\
\hline 10. & Economic Motivation & $0.495^{*}$ & 0.023 \\
\hline 11. & $\begin{array}{l}\text { Awareness regarding alternative } \\
\text { stubble management measures }\end{array}$ & $0.012^{\mathrm{NS}}$ & 0.260 \\
\hline 12. & Cropping intensity & $0.041^{\mathrm{NS}}$ & 0.518 \\
\hline
\end{tabular}

NS: Non-Significant

** Correlation is significant at the 0.05 level (2-tailed).

Table.2 Chi-square statistics regarding Gender and Stubble burning Behaviour

\begin{tabular}{|c|c|c|c|c|c|}
\hline & \multicolumn{2}{|c|}{ Gender } & \multirow[t]{2}{*}{ Total } & \multirow{2}{*}{$\chi^{2}$ value } \\
\hline & & Female & Male & & \\
\hline \multirow{3}{*}{$\begin{array}{c}\text { Stubble } \\
\text { Burning } \\
\text { Behaviour }\end{array}$} & High & $\begin{array}{c}13 \\
(11.8)\end{array}$ & $\begin{array}{c}119 \\
(120.2)\end{array}$ & $\begin{array}{c}132 \\
(132)\end{array}$ & \multirow{4}{*}{$\begin{array}{c}\chi^{2}(\mathrm{cal})= \\
3.903 \\
\chi^{2}(\mathrm{tab})= \\
5.991\end{array}$} \\
\hline & Low & $\begin{array}{c}1 \\
(4.4)\end{array}$ & $\begin{array}{c}48 \\
(44.6)\end{array}$ & $\begin{array}{c}49 \\
(49)\end{array}$ & \\
\hline & Medium & $\begin{array}{c}8 \\
(5.8)\end{array}$ & $\begin{array}{c}57 \\
(59.2)\end{array}$ & $\begin{array}{c}65 \\
(65)\end{array}$ & \\
\hline \multicolumn{2}{|c|}{ Total } & $\begin{array}{c}22 \\
(22)\end{array}$ & $\begin{array}{c}224 \\
(224)\end{array}$ & $\begin{array}{c}246 \\
(246)\end{array}$ & \\
\hline
\end{tabular}

Degrees of freedom $=2$

*Expected count is given in brackets 
Table.3 Chi-square statistics regarding education and stubble burning behaviour

\begin{tabular}{|c|c|c|c|c|c|c|c|c|c|c|}
\hline & \multicolumn{7}{|c|}{ Education } & \multirow{2}{*}{$\begin{array}{c}\text { Tota } \\
\mathbf{l}\end{array}$} & \multirow{2}{*}{$\begin{array}{c}\chi^{2} \\
\text { value }\end{array}$} \\
\hline & & $\begin{array}{c}\text { Illiterat } \\
\mathrm{e}\end{array}$ & $\begin{array}{c}\text { Functionall } \\
\text { y literate }\end{array}$ & $\begin{array}{c}\text { Primary } \\
\text { educatio } \\
n\end{array}$ & $\begin{array}{c}\text { High } \\
\text { Schoo } \\
1\end{array}$ & $\begin{array}{c}\text { Intermediat } \\
\mathrm{e}\end{array}$ & $\begin{array}{c}\text { Graduat } \\
\mathrm{e}\end{array}$ & $\begin{array}{c}\text { Post } \\
\text { Graduat } \\
\text { e }\end{array}$ & & \\
\hline \multirow{3}{*}{$\begin{array}{c}\text { Stubble } \\
\text { Burning } \\
\text { Behaviou } \\
\text { r }\end{array}$} & High & $\begin{array}{c}8 \\
(9.1)\end{array}$ & $\begin{array}{c}19 \\
(16.1)\end{array}$ & $\begin{array}{c}15 \\
(17.2)\end{array}$ & $\begin{array}{c}24 \\
(25.2)\end{array}$ & $\begin{array}{c}27 \\
(29)\end{array}$ & $\begin{array}{c}30 \\
(28.4)\end{array}$ & $\begin{array}{c}9 \\
(7)\end{array}$ & $\begin{array}{c}132 \\
(132)\end{array}$ & \multirow{4}{*}{$\begin{array}{c}\chi 2(\mathrm{cal}) \\
=8.720 \\
\chi 2(\mathrm{tab}) \\
=21.02 \\
6\end{array}$} \\
\hline & Low & $\begin{array}{c}5 \\
(3.4)\end{array}$ & $\begin{array}{c}5 \\
(6)\end{array}$ & $\begin{array}{c}7 \\
(6.4)\end{array}$ & $\begin{array}{c}13 \\
(9.4)\end{array}$ & $\begin{array}{c}8 \\
(10.8)\end{array}$ & $\begin{array}{c}9 \\
(10.6)\end{array}$ & $\begin{array}{c}2 \\
(2.6)\end{array}$ & $\begin{array}{c}49 \\
(49)\end{array}$ & \\
\hline & $\begin{array}{l}\text { Mediu } \\
\text { m }\end{array}$ & $\begin{array}{c}4 \\
(4.5)\end{array}$ & $\begin{array}{c}6 \\
(7.9)\end{array}$ & $\begin{array}{c}10 \\
(8.5)\end{array}$ & $\begin{array}{c}10 \\
(12.4)\end{array}$ & $\begin{array}{c}19 \\
(14.3)\end{array}$ & $\begin{array}{c}14 \\
(14)\end{array}$ & $\begin{array}{c}2 \\
(3.4)\end{array}$ & $\begin{array}{c}65 \\
(65)\end{array}$ & \\
\hline \multicolumn{2}{|c|}{ Total } & $\begin{array}{c}17 \\
(17)\end{array}$ & $\begin{array}{c}30 \\
(30)\end{array}$ & $\begin{array}{c}32 \\
(32)\end{array}$ & $\begin{array}{c}47 \\
(47)\end{array}$ & $\begin{array}{c}54 \\
(54)\end{array}$ & $\begin{array}{c}53 \\
(53)\end{array}$ & $\begin{array}{c}13 \\
(13)\end{array}$ & $\begin{array}{c}89 \\
(89)\end{array}$ & \\
\hline
\end{tabular}

Degrees of freedom $=21$

*Expected count is given in brackets

Table.4 Chi-square statistics regarding type of farming and stubble burning Behaviour

\begin{tabular}{|c|c|c|c|c|c|c|}
\hline & \multicolumn{3}{|c|}{ Type of farming } & \multirow[t]{2}{*}{ Total } & \multirow[t]{2}{*}{$\chi^{2}$ value } \\
\hline & & Diversified & Mixed & Specialized & & \\
\hline \multirow{3}{*}{$\begin{array}{c}\text { Stubble } \\
\text { Burning } \\
\text { Behaviour }\end{array}$} & High & $\begin{array}{c}37 \\
(33.8)\end{array}$ & $\begin{array}{c}34 \\
(37.6)\end{array}$ & $\begin{array}{c}61 \\
(60.6)\end{array}$ & $\begin{array}{c}132 \\
(132)\end{array}$ & \multirow{4}{*}{$\begin{array}{c}\chi^{2}(\mathrm{cal})= \\
4.661 \\
\chi^{2}(\mathrm{tab})= \\
9.448\end{array}$} \\
\hline & Low & $\begin{array}{c}7 \\
(12.5)\end{array}$ & $\begin{array}{c}17 \\
(13.9)\end{array}$ & $\begin{array}{c}25 \\
(22.5)\end{array}$ & $\begin{array}{c}49 \\
(49)\end{array}$ & \\
\hline & Medium & $\begin{array}{c}19 \\
(16.6)\end{array}$ & $\begin{array}{c}19 \\
(18.5)\end{array}$ & $\begin{array}{c}27 \\
(29.9)\end{array}$ & $\begin{array}{c}65 \\
(65)\end{array}$ & \\
\hline \multicolumn{2}{|c|}{ Total } & $\begin{array}{c}63 \\
(63)\end{array}$ & $\begin{array}{c}70 \\
(70)\end{array}$ & $\begin{array}{c}113 \\
(113)\end{array}$ & $\begin{array}{c}246 \\
(246)\end{array}$ & \\
\hline
\end{tabular}

Degrees of freedom $=4$

*Expected count is given in brackets

The results of chi-square test as shown in Table 4 reveals that the calculated chi-square value was $4.661\left(\square^{2}\right.$ cal $\left.=4.661\right)$ while the tabulated chi-square value was $9.448\left(\square^{2} \mathrm{tab}=\right.$ 9.448) at 4 degrees of freedom. This indicates that chi-square calculated value was less than chi-square tabulated $\left(\square^{2}\right.$ cal $<\square^{2}$ tab), which means that both the variables, type of farming and stubble burning behaviour of the farmers were independent. Hence, null hypothesis $\mathrm{H}_{015}$ was accepted.

The results reveal the relationship between the variables related to profile characteristics and stubble burning behaviour of the farmers.
It was found that the relationship between profile variables like age, size of land holding, livestock possession, innovativeness, risk orientation, scientific orientation, ecological consciousness, awareness regarding alternative stubble management measures, cropping intensity, annual income and information seeking behaviour; and stubble burning behaviour of the farmers was nonsignificant. The strength of the correlation between these variables and stubble burning behaviour of the farmers was very weak, denoted by a very less 'r-value' and 'p-value' was more than 0.05 in case of each variable. Thus, hypotheses which stated the 
relationship between these variables and stubble burning behaviour, $\mathrm{H}_{01}, \mathrm{H}_{02}, \mathrm{H}_{03}, \mathrm{H}_{04}$, $\mathrm{H}_{05}, \mathrm{H}_{06}, \mathrm{H}_{07}, \mathrm{H}_{08}, \mathrm{H}_{09}, \mathrm{H}_{011}, \mathrm{H}_{012}$ were accepted.

It was found that economic motivation was the lone variable to have a positive and significant relationship with the stubble burning behaviour of the farmers. The ' $r$ value' in case of economic motivation was 0.495 which reflects its moderate strength of relationship with the stubble burning behaviour of the farmers. The observed ' $p$ value' for economic motivation was 0.023 , which was less than 0.05 , indicating that the relationship was significant. Hence, null hypothesis, which stated that "There is no significant relationship between economic motivation of the farmers and their stubble burning behaviour", $\mathrm{H}_{010}$ was rejected.As most of the farmers were having high economic motivation, this might be one of the key factors in choosing a stubble management measure. Since, stubble burning is the most economical measure available, most of the farmers preferred it instead of going for other alternatives. This also helps in deducing the reason behind farmers reverting back to burning after trying the alternative measures as they were costly and didn't yield fruitful results.

On the other hand, the relationship between variables with grouped data like gender, education and type of farming; and the stubble burning behaviour were analyzed through chi-square test. The results of chisquare statistics for these variables are given Table 45, 46 and 47 respectively. The data shows that in case of all the three variables; gender, education and type of farming, chisquare calculated values were less than chisquare tabulated values $\left(\square^{2}\right.$ cal $<\square^{2}$ tab) at respective degrees of freedom. Therefore, they were independent of stubble burning behaviour of the farmers. Hence, hypotheses stubble burning behaviour were independent of stubble burning behaviour of the farmers. Hence, hypotheses $\mathrm{H}_{013}, \mathrm{H}_{014}$ and $\mathrm{H}_{015}$ were accepted.

\section{Acknowledgements}

I, Arpit Huria, owe huge gratitude to Dr. Neelam Bhardwaj, without whose guidance, this study would have not been possible. A heartfelt thanks to Dr. Neelam Basera, who provided immensely valuable suggestions to bring this manuscript to shape. I also thank Indian Council of Social Science Research for providing financial assistance for conducting this study. Finally, thanks to all family member and friends who supported physically, mentally, emotionally and spiritually in completion of this study.

\section{References}

Chakrabarti, S., Khan, M.T., Kishore, A., Roy, D. and Scott, S.P. 2019. Risk of acute respiratory infection from Crop burning in India: Estimating disease burden and economic welfare from satellite and national health survey data for 250000 persons. International Journal of Epidemiology, 1:1-12.

Chhabra, A., Sehgal, V. K., Dhakar, R., Jain, N. and Verma, R. 2019. Monitoring of active fire events due to paddy residue burning in Indo-Gangetic plains using thermal remote sensing. The International Archives of the Photogrammetry, Remote Sensing and Spatial Information Sciences, XLII3/W6, 649-657, https://doi.org/10.5194/isprs-archivesXLII-3-W6-649-2019.

Jain, N., Bhatia, A. and Pathak, H. 2014. Emission of Air Pollutants from Crop Residue Burning in India. Aerosol and Air Quality Research, 14: 422-430.

Kumar, P., Kumar, S. and Joshi, L.2015. Socioeconomic and Environmental 
Implications of Agricultural Residue Burning: A case study of Punjab, India. Springer Briefs in Environmental Science, pp. 144.

Kumar, P., Rajpoot, S. K., Jain, V., Saxena, S., Neetu. and Ray. S. S. 2019. Monitoring of rice crop in Punjab and
Haryana with respect to residue burning. The International Archives of the Photogrammetry, Remote Sensing and Spatial Information Sciences, XLII3/W6, 31-36. Retrieved from https://doi.org/10.5194/isprs-archivesXLII-3-W6-31-2019.

\section{How to cite this article:}

Arpit Huria, Neelam Bhardwaj and Neelam Basera. 2021. Effect of Profile Characteristics on Stubble Burning Behaviour of farmers in Punjab. Int.J.Curr.Microbiol.App.Sci. 10(02): 32833293. doi: https://doi.org/10.20546/ijcmas.2021.1002.361 